\title{
ANALISIS EVAKUASI BENCANA TSUNAMI DI GEDUNG KULIAH BERSAMA V UNIVERSITAS BENGKULU DENGAN METODE AGENT BASED MODELLING
}

\author{
Ade Sahroli $^{1}$, Hardiansyah $^{1)}$ \\ ${ }^{1)}$ Program Studi Teknik Sipil, Fakultas Teknik, Universitas Bengkulu \\ Jl. W.R. Supratman, Kandang Limun, Bengkulu 38371, Telp (0736) 344087 \\ Coresponding Author: adesahroli2@gmail.com
}

\begin{abstract}
Abstrak
Penelitian ini memodelkan pergerakan pengungsi bencana tsunami di Gedung Kuliah Bersama V Universitas Bengkulu dengan metode agent based modelling. Kuisioner dilakukan untuk mengetahui moda transportasi yang digunakan, kemudian diolah dengan mencari derajat kejenuhan, volume, kapasitas jalan, kecepatan dan waktu tempuh. Penelitian ini membandingkan antara pergerakan harian dan saat evakuasi, maka dilakukan analisis regresi linier sederhana. Terdapat beberapa ruas jalan dan rute alternatif yang ditinjau pada penelitian ini. Hasil penelitian menunjukan bahwa rute yang banyak dipilih oleh responden saat evakuasi adalah rute terpendek menuju gerbang keluar. Derajat kejenuhan yang didapat masih dalam kategori stabil, namun perlu pengembangan kinerja jaringan jalan lokal Universitas Bengkulu supaya dalam proses evakusi dapat berjalan dengan baik.
\end{abstract}

Kata kunci: tsunami, evakuasi, agent based modelling

\begin{abstract}
This study modeled the movement of tsunami refugees at Gedung Kuliah Bersama V University of Bengkulu with an agent based modeling method. The questionnaire was conducted to find out the modes of transportation used, then processed by finding the saturation of degree, volume, road capacity, speed and travel time. This study compares the daily movement and time of evacuation, then a simple linear regression analysis is carried out. There are several road segments and alternative routes that were reviewed in this study. The results showed that the route chosen by respondents during evacuation was the shortest route to the exit gate. The saturation of degree obtained was still in the stable category. However, there is a necessary to develop the performance of university of bengkulu road networks which can enjure the better evacuation process.
\end{abstract}

Keywords: tsunami, evacuatin, agent based modelling 


\section{PENDAHULUAN}

\section{Tsunami}

Tsunami terdiri dari rangkaian gelombang laut yang mampu menjalar dengan kecepatan mencapai lebih dari $900 \mathrm{~km} / \mathrm{jam}$ atau lebih di tengah laut. Jenis bencana ini disebabkan oleh beberapa faktor, antara lain gempa bumi yang terjadi di dasar laut, runtuhan di dasar laut, atau karena letusan gunung api di laut (BNPB, 2017).

\section{Evakuasi Bencana}

Mengevakuasi populasi dalam skala besar merupakan pekerjaan yang sangat rumit dan sulit, sangat bergantung pada pemanfaatan sistem transportasi secara efisien, dan skema evakuasi yang efektif. Salah satu faktor penting yang mempengaruhi kinerja evakuasi adalah waktu keberangkatan yang dipilih oleh pengungsi. Keberangkatan pengungsi yang simultan dapat mengakibatkan penuhnya jaringan jalan dan kemacetan (Hardiansyah dkk, 2016).

\section{Kinerja Jaringan Jalan}

Panduan Kapasitas Jalan Indonesia (2014) kinerja ruas jalan didefiniskan sebagai ukuran kuantitatif yang menerangkan kondisi operasional fasilitas ruas jalan. Suwardi (2008) menyatakan bahwa kinerja ruas jalan adalah kemampuan ruas jalan untuk melayani kebutuhan arus lalu lintas sesuai dengan fungsinya yang dapat diukur dengan standar tingkat pelayanan jalan. Nilai tingkat pelayanan jalan dijadikan sebagai parameter kinerja ruas jalan.

\section{Kapasitas Jalan}

Kapasitas didefinisikan sebagai arus lalu lintas maksimum dalam satuan ekr/jam yang dapat dipertahankan sepanjang segmen jalan tertentu dalam kondisi tertentu, yaitu meliputi geometrik, lingkungan dan lalu lintas (PKJI, 2014).
Persamaan dasar untuk menentukan kapasitas adalah sebagai berikut:

$\mathrm{C}=\mathrm{C}_{\mathrm{o}} \times \mathrm{FC}_{\mathrm{Lj}} \times \mathrm{FC}_{\mathrm{PA}} \times \mathrm{FC}_{\mathrm{HS}} \times \mathrm{FC}_{\mathrm{UK}}$

Keterangan:

$$
\begin{aligned}
\mathrm{C}= & \text { kapasitas (skr/jam) } \\
\mathrm{C}_{\mathrm{o}}= & \text { kapasitas dasar (skr/jam) } \\
\mathrm{FC}_{\mathrm{Lj}}= & \text { faktor penyesuaian kapasitas } \\
& \text { terkait lebar lajur atau jalur lalu } \\
& \text { lintas. } \\
\mathrm{FC}_{\mathrm{PA}}= & \text { faktor penyesuaian kapasitas } \\
& \text { terkait pemisahan arah, hanya } \\
& \text { pada jalan tak terbagi. } \\
\mathrm{FC}_{\mathrm{HS}}= & \text { faktor penyesuaian kapasitas } \\
& \text { terkait KHS pada jalan berbahu } \\
& \text { atau berkereb. } \\
\mathrm{FC}_{\mathrm{UK}}= & \text { faktor penyesuaian kapasitas } \\
& \text { terkait ukuran kota. }
\end{aligned}
$$

\begin{tabular}{|c|c|c|c|}
\hline Tipe Jalan & $\begin{array}{r}\text { Lebar jalu } \\
\text { efektif }\end{array}$ & $\begin{array}{l}\text { r lalu lintas } \\
\text { (Wc) (m) }\end{array}$ & $\mathrm{FC}_{\mathrm{Lj}}$ \\
\hline \multirow{5}{*}{$\begin{array}{l}4 / 2 \mathrm{~T} \text { atau } \\
\text { jalan satu- } \\
\text { arah }\end{array}$} & \multirow{5}{*}{$\begin{array}{l}\text { Lebar per } \\
\text { Lajur }\end{array}$} & 3 & 0,92 \\
\hline & & 3,25 & 0,96 \\
\hline & & 3,5 & 1 \\
\hline & & 3,75 & 1,04 \\
\hline & & 4 & 1,08 \\
\hline \multirow[t]{6}{*}{$2 / 2 \mathrm{TT}$} & Lebar jalur & 5 & 0,56 \\
\hline & 2 arah & 6 & 0,87 \\
\hline & & 7 & 1 \\
\hline & & 8 & 1,24 \\
\hline & & 9 & 1,25 \\
\hline & & 10 & 1,29 \\
\hline
\end{tabular}

Tabel 1. Kapasitas Jalan

\begin{tabular}{lcl}
\hline Tipe Jalan & $\begin{array}{c}\mathbf{C}_{\mathrm{o}} \\
\text { (skr/jam) }\end{array}$ & Catatan \\
\hline \multirow{2}{*}{$\begin{array}{l}\text { 4/2TT atau } \\
\text { jalan satu- }\end{array}$} & 1650 & $\begin{array}{l}\text { per lajur } \\
\text { (satu arah) }\end{array}$ \\
\cline { 2 - 3 } arah 2/2TT & 2900 & $\begin{array}{l}\text { per jalur } \\
\text { (dua arah) }\end{array}$ \\
\hline sumber: PKJI, 2014 &
\end{tabular}

Tabel 2. Faktor Penyesuaian Kapasitas Terkait Lebar Lajur Lalu Lintas (FCLj)

sumber: PKJI, 2014 
Tabel 3. Faktor Penyesuaian Kapasitas Akibat Pemisahan Arah Lalu Lintas (FCPA)

\begin{tabular}{l|c|c|c|c|c}
\hline $\begin{array}{c}\text { Pemisahan } \\
\text { Arah PA } \\
\mathbf{\%}-\mathbf{0}\end{array}$ & $\mathbf{5 0 - 5 0}$ & $\mathbf{5 5 - 4 5}$ & $\mathbf{6 0 - 4 0}$ & $\mathbf{6 5 - 3 5}$ & $\mathbf{7 0 - 3 0}$ \\
\hline $\begin{array}{l}\text { FCPA } 2 / 2 \\
\text { TT }\end{array}$ & 1 & 0,97 & 0,94 & 0,91 & 0,88 \\
\hline
\end{tabular}

Tabel 4. Faktor Penyesuaian Kapasitas Akibat Hambatan Samping (FCHS)

\begin{tabular}{|c|c|c|c|c|c|}
\hline \multirow{3}{*}{$\begin{array}{l}\text { Tipe } \\
\text { Jalan }\end{array}$} & \multirow{3}{*}{$\begin{array}{c}\text { Kelas } \\
\text { Hambata } \\
\mathbf{n} \\
\text { Samping }\end{array}$} & \multirow{2}{*}{\multicolumn{4}{|c|}{$\begin{array}{c}\text { Faktor penyesuaian akibat hambatan } \\
\text { samping (FCHS) }\end{array}$}} \\
\hline & & & & & \\
\hline & & $<0,5$ & 1 & 1,5 & $>2,0$ \\
\hline \multirow[t]{7}{*}{$4 / 2 \mathrm{~T}$} & Sangat & 0,96 & 0,98 & 1,01 & $-1,03$ \\
\hline & Rendah & & & & \\
\hline & Rendah & 0,94 & 0,97 & 1 & 1,02 \\
\hline & Sedang & 0,92 & 0,95 & 0,98 & 1 \\
\hline & Tinggi & 0,88 & 0,92 & 0,95 & 0,98 \\
\hline & Sangat & 0,84 & 0,88 & 0,92 & 0,96 \\
\hline & Tinggi & & & & \\
\hline \multirow[t]{2}{*}{$2 / 2 \mathrm{TT}$} & Sangat & 0,94 & 0,96 & 0,99 & 1,01 \\
\hline & Rendah & & & & \\
\hline \multirow[t]{5}{*}{$4 / 2 \mathrm{TT}$} & Rendah & 0,92 & 0,94 & 0,97 & 1 \\
\hline & Sedang & 0,89 & 0,92 & 0,95 & 0,98 \\
\hline & Tinggi & 0,82 & 0,86 & 0,9 & 0,95 \\
\hline & Sangat & 0,73 & 0,79 & 0,85 & 0,91 \\
\hline & Tinggi & & & & \\
\hline
\end{tabular}

Tabel 5. Faktor Penyesuaian Kapasitas Terkait Ukuran Kota

\begin{tabular}{|c|c|}
\hline $\begin{array}{l}\text { Ukuran Kota (juta } \\
\text { penduduk) }\end{array}$ & $\begin{array}{l}\text { Faktor Penyesuaian } \\
\text { untuk Ukuran Kota, } \\
\text { FCUK }\end{array}$ \\
\hline$<0,1$ & 0,86 \\
\hline $0,1-0,5$ & 0,9 \\
\hline $0,5-1,0$ & 0,94 \\
\hline $1,0-3,0$ & 1 \\
\hline$>0,3$ & 1,04 \\
\hline
\end{tabular}

sumber: PKJI, 2014

\section{Derajat Kejenuhan}

Menurut PKJI (2014) derajat kejenuhan atau kecepatan tempuh merupakan hal-hal yang mempengaruhi kriteria kinerja lalu lintas pada suatu kondisi jalan tertentu terkait dengan geometrik, arus lalu lintas, dan lingkungan jalan baik untuk kondisi desain maupun kondisi eksisting. Semakin rendah nilai derajat kejenuhan atau semakin tinggi kecepatan tempuh menunjukkan semakin baik kinerja lalu lintas. Nilai derajat kejenuhan diperoleh melalui persamaan berikut:

$$
\mathrm{Dj}=\frac{\mathrm{Q}}{\mathrm{C}}
$$

Keterangan:

$$
\begin{array}{ll}
\mathrm{Dj} & =\text { derajat kejenuhan } \\
\mathrm{Q} & =\text { arus lalu lintas total }(\mathrm{skr} / \mathrm{jam}) \\
\mathrm{C} & =\text { kapasitas }(\mathrm{skr} / \mathrm{jam})
\end{array}
$$

Permodelan Transportasi untuk

\section{Evakuasi}

Permodelan transportasi untuk evakuasi yang berbasis perilaku pengungsi memiliki keuntungan, yaitu setiap individu pengungsi dalam model dapat ditambahkan kemampuan intelektual dan pengetahuan akan evakuasi, hanya konsep ini cakupan wilayah kajiannya sangat terbatas (mikro). Konsep model transportasi evakuasi berbasis kinerja jaringan jalan memiliki keuntungan, yaitu dapat memodelkan pergerakan lalulintas akibat proses evakuasi dalam skala yang besar (Hardiansyah dkk, 2016).

\section{Permodelan Berbasis Agen Based Modeling (ABM) dengan Netlogo}

Dalam www.adagnitio.wordpress.com menjelaskan bahwa Agent Based Modelling (ABM) adalah model simulasi yang menggambarkan individu-individu (agen) dalam sebuah sistem yang kompleks dan dinamis. Konsep dasar $A B M$ yaitu:

a) ABM merepresentasikan sebuah sistem yang komponennya berupa individu dan perilakunya.

b) ABM memodelkan agen individu bukan hanya memodelkan variabel-variabel yang merepresentasikan keseluruhan sistem. 
c) Agen mempunyai sifat heterogen dan otonom serta dapat berinteraksi antar agen dan lingkungannya.

d) Agen mempunyai sifat adaptif dimana agen dapat menyesuaikan diri dengan kondisinya saat ini, dengan agen yang lain, dan dengan lingkungannya.

e) Agen menangani masalah yang berhubungan dengan emergence (sistem dinamis yang muncul akibat hubungan antar agen atau antara agen dengan lingkungannya).

f) ABM berhubungan dengan 2 atau lebih level dan saling berinteraksi.

g) ABM dapat menjelaskan hubungan timbal balik antara sistem dan individu (apa yang terjadi pada sistem karena perilaku individu dan apa yang terjadi pada individu karena kerja sistem)

Jumadi dkk., (2016) mengembangkan simulasi evakuasi di lingkungan berbasis komputer untuk mengidentifikasi kemungkinan masalah rencana dalam berbagai skenario menggunakan Agent Based Modelling dan Sistem Informasi Geografis (ABM-GIS) yang bertujuan untuk memberikan kerangka kerja konseptual pengembangan simulasi evakuasi gunung berapi.

\section{Populasi Sampel}

Sampel adalah suatu himpunan bagian (subset) dari unit populasi. Sampel terdiri dari bagian populasi yang memiliki karakteristik yang relatif sama dan dianggap mewakili populasi (Mudrajad, 2003 dalam Rahma, 2010). Menentukan jumlah sampel dapat menggunakan rumus untuk menentukan besaran sampel dalam penelitian yaitu rumus Slovin sebagai berikut:

$\mathrm{N}=\frac{\mathrm{N}}{1+\mathrm{N}\left(\mathrm{e}^{2}\right)}$
Keterangan:

n = jumlah responden

$\mathrm{N} \quad=$ jumlah populasi

e $=$ persentase kelonggaran karena kesalahan pengambilan sampel

\section{METODE PENELITIAN}

\section{Lokasi Penelitian}

Lokasi penelitian ini bertempat di Gedung Kuliah Bersama V Universitas Bengkulu. Gedung Kuliah Bersama V Universitas Bengkulu terletak di Universitas Bengkulu bagian belakang atau biasa disebut UNIB Belakang. Bagian depan gedung berhadapan dengan GKB III dan IV, bagian kanan gedung berseberangan dengan Gedung Fakultas Kedokteran yang dimana antara gedung ini dipisah oleh sawah, bagian belakang gedung terdapat kebun sawit, dan bagian kiri gedung terdapat sawah.

\section{Data yang Digunakan}

Berikut merupakan data yang digunakan dalam penelitian ini:

\section{Data Primer}
a) Geometri jalan Universitas Bengkulu.
b) Kapasitas kepadatan kendaraan
c) kuisioner

2. Data Sekunder

a) Peta jaringan jalan Universitas Bengkulu.

b) Data mahasiswa, dosen dan karyawan.

c) Studi literatur, antara lain dari jurnal, artikel hasil riset dan buku.

\section{Karakteristik Pengguna Gedung}

Gedung Kuliah Bersama V Universitas Bengkulu ini digunakan untuk belajar mengajar oleh Fakultas Teknik dan Fakultas Matematika dan Ilmu Pengetahuan Alam. Persentase pengguna terlihat pada Gambar 1. 


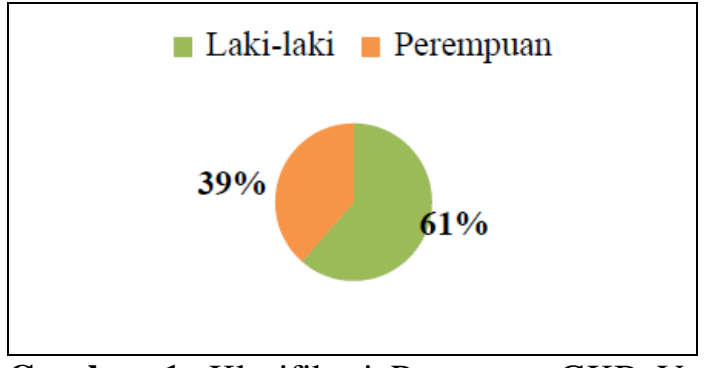

Gambar 1. Klasifikasi Pengguna GKB V Berdasarkan Jenis Kelamin

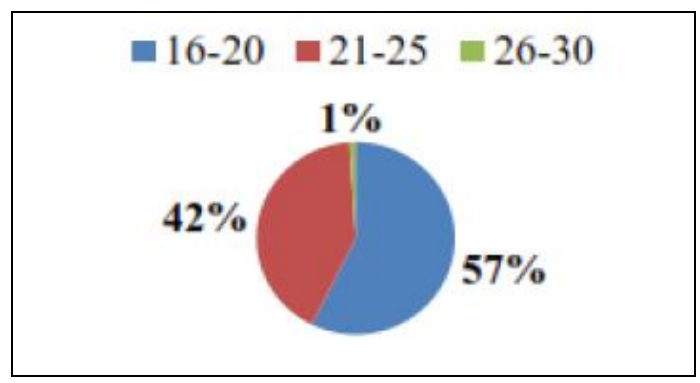

Gambar 2. Klasifikasi Pengguna GKB V Berdasarkan Umur

\section{Sarana Transportasi Pengguna Gedung}

Sarana transportasi pengguna Gedung Kuliah Bersama V Universitas Bengkulu terdiri dari kendaraan ringan (LV) dan sepeda motor (MC), dimana letak parkir kendaraan ringan berada pada bagian depan gedung dan letak parkir sepeda motor berada pada depan, samping dan belakang gedung. Data kendaraan yang parkir di halaman Gedung Kuliah Bersama V Universitas Bengkulu berdasarkan survei parkir tanggal 13 Mei 2019 selama 1 hari jam kerja dapat dilihat pada Lampiran 1. Grafik kendaraan yang parkir di halaman Gedung Kuliah Bersama V Universitas Bengkulu dapat dilihat pada Gambar 3.

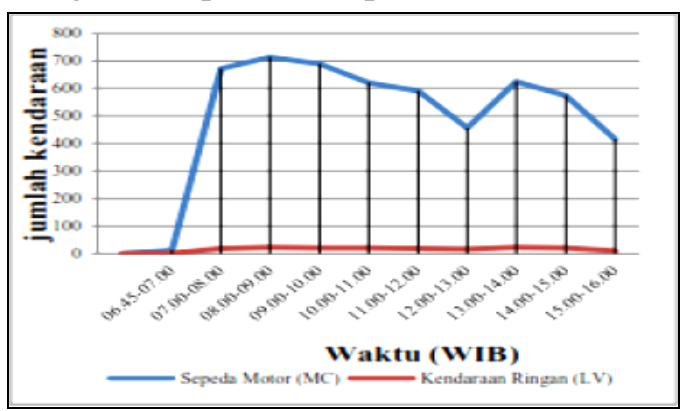

Gambar 3. Grafik Kendaraan yang Parkir di Halaman Gedung Kuliah Bersama V
Moda transportasi harian pada Gedung Kuliah Bersama V Universitas Bengkulu berdasarkan survei parkir didapat waktu puncak yang terjadi yaitu pada pukul 09.00 WIB, dimana waktu puncak ini akan menjadi acuan penulis untuk

mengasumsikan waktu terjadinya bencana gempa bumi dan tsunami. Persentase moda transportasi harian pada Gedung Kuliah Bersama V Universitas Bengkulu berdasarkan survei parkir diperoleh hasil sebagai berikut:

$\begin{array}{ll}\text { 1. }(\mathrm{MC}) & =96,875 \% \\ \text { 2. }(\mathrm{LV}) & =3,125 \\ \text { 3. }(\mathrm{HV}) & =0 \%\end{array}$

\section{Jaringan Jalan}

Terdapat 2 alternatif rute yang ditawarkan kepada pengguna Gedung Kuliah Bersama V Universitas Bengkulu. Rute 1 yaitu dari GKB $\mathrm{V}$ menuju gerbang keluar UNIB belakang (FT) dan rute 2 dari GKB V menuju gerbang keluar Unib belakang (FISIP). $100 \%$ agen memilih rute 1 yaitu dari GKB V menuju gerbang keluar UNIB belakang (FT). Ruas jalan diambil antara setiap simpang dengan nama R-01 dan R02, dimana R-01 adalah ruas jalan dari GKB V sampai Fakultas Teknik dan R-02 adalah ruas jalan dari Fakultas Teknik sampai gerbang keluar UNIB belakang (FT). Rute alternatif dapat dilihat pada Gambar 4.

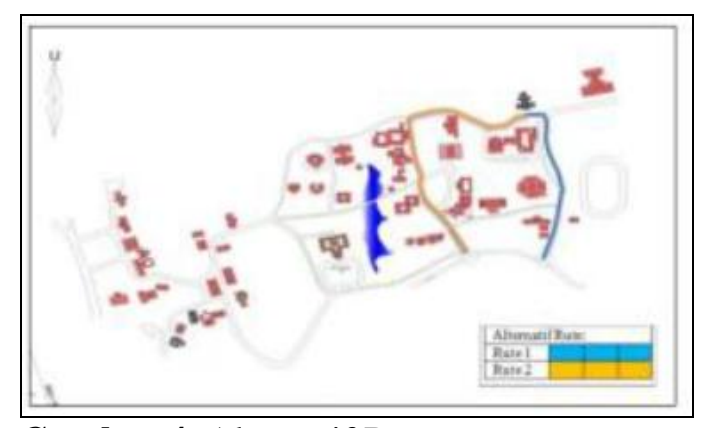

Gambar 4. Alternatif Rute 


\section{HASIL PEMODELAN}

Salah satu sifat dari NetLogo adalah bahwa output permodelan dari agent yang dihasilkan bersifat stokastik, artinya hasil yang terjadi selalu berubah setiap kali simulasi dilakukan. Grafik hasil simulasi pengembangan NetLogo pada penelitian ini dapat dilihat pada Gambar 5.

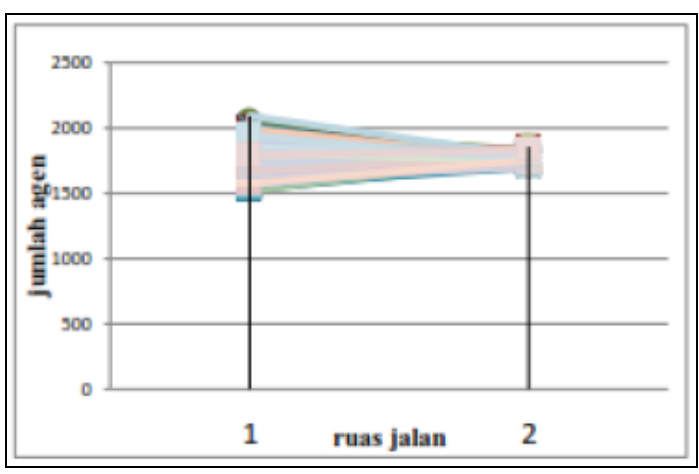

Gambar 5. Grafik Hasil Pemodelan yang Dilakukan

Hasil dari output pada simulasi berulang yang telah dilakukan diambil rata-rata nilai guna mendapatkan nilai terbaik. Maka, ratarata agent yang melalui ruas jalan dalam bentuk koma akan dilakukan pembulatan. Data output rata-rata hasil simulasi dapat dilihat pada Tabel 6.

Tabel 6. Data Output Rata-Rata Hasil Pemodelan

\begin{tabular}{c|c|c}
\hline No. & Kode Jalan & $\begin{array}{c}\text { Volume Model } \\
\text { (orang) }\end{array}$ \\
\hline 1 & R-01 & 1769 \\
\hline 2 & R-02 & 1762 \\
\hline
\end{tabular}

\section{Validasi Model}

Validasi model dilakukan untuk melihat bagaimana perbandingan antara kondisi nyata dan kondisi permodelan, maka dilakukan dengan menggunakan regresi linier sederhana yang dapat dilhat pada Tabel 7.
Tabel 7. Regresi Linier Sederhana

\begin{tabular}{|c|c|c|c|c|}
\hline \multirow{2}{*}{$\begin{array}{c}\text { Kode Jalan yang } \\
\text { Digunakan }\end{array}$} & $\mathrm{X}$ & $Y$ & \multirow[b]{2}{*}{$\mathrm{XY}$} & \multirow[b]{2}{*}{$\mathrm{X}^{2}$} \\
\hline & $\begin{array}{c}\text { Volume } \\
\text { Pergerakan }\end{array}$ & $\begin{array}{c}\text { Volume } \\
\text { Pergerakan }\end{array}$ & & \\
\hline R-01 & 1970 & 1769 & 17490 & 23705 \\
\hline R-02 & 1970 & 1762 & 46248 & 45887 \\
\hline Jumlah & 3940 & 3531 & $7 E+06$ & 7761800 \\
\hline Rata-Rata & 1970 & 1765,5 & & \\
\hline
\end{tabular}

Dari tabel diatas diperoleh $\mathrm{R}_{2}=0,9987=$ 99,87\%. Hal itu menunjukkan bahwa volume pergerakan model yang dibangun telah memiliki kesamaan dengan volume pergerakan kondisi riil ( $\mathrm{R}_{2}$ mendekati 100\%). Grafik yang terbentuk dari persamaan tersebut dapat dilihat pada Gambar 6.

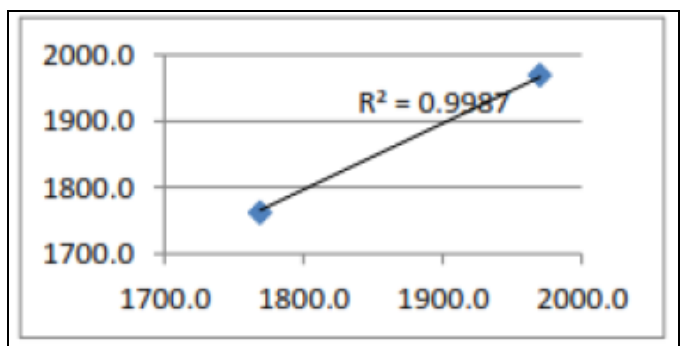

Gambar 6. Grafik Perbandingan Pergerakan Harian dan Pergerakan Model

\section{Analisis Kinerja Model}

Analisis output pada NetLogo dilakukan melalui pengolahan data hasil simulasi, menghitung kapasitas ruas jalan, dan menghitung derajat kejenuhan $(D J)$ pada ruas jalan yang dilalui oleh agent.

\section{Derajat Kejenuhan}

Hasil konversi model dan hitungan kapasitas ruas jalan yang sudah ditinjaui selanjutnya dilakukan perhitungan derajat kejenuhan $\left(D_{J}\right) . \quad$ Rekapitulasi hasil perhitungan derajat kejenuhan dianalisis untuk perjalanan harian dan perjalanan evakuasi dapat dilihat pada Tabel.8. 
Tabel 8. Rekapitulasi Hasil Perhitungan Derajat Kejenuhan $\left(D_{\mathrm{J}}\right)$

\begin{tabular}{|c|c|c|c|c|c|c|c|}
\hline \multirow{2}{*}{ No. } & \multirow{2}{*}{ Kode Jalan } & \multicolumn{2}{|c|}{$\begin{array}{c}\text { Volume Model } \\
\text { (skrjiam) }\end{array}$} & \multicolumn{2}{|c|}{ Kapassitas Jalan (sky jam) } & \multicolumn{2}{|c|}{ Derzajat Kejenuhan } \\
\hline & & Harian & Evakasis: & Harian & Evahuasi & Harian & Evakhas \\
\hline 1 & $R \cdot 01$ & 710,4 & 386,4 & 131 & 11119 & 0,5411 & 0,3454 \\
\hline & R.O2 & 710,4 & 385,2 & 1441 & 1119 & 0,4931 & 0,3443 \\
\hline
\end{tabular}

\section{Kecepatan dan Waktu Tempuh}

Waktu tempuh pergerakan agen bisa diamati secara manual pada NetLogo. 1000 ticks pada NetLogo diperoleh waktu 8 menit 55 detik. Sehingga waktu 1 detik merepresentasikan 1,935 ticks pada NetLogo.

Waktu tempuh yang dilalui agen merupakan waktu agen mengosongkan ruas jalan. Hasil dari waktu yang diperoleh selanjutnya dicatat pada setiap ruas jalan, sehingga kecepatan bisa dicari. Rekapitulasi waktu tempuh dan kecepatan dalam ruas jalan akan dibandingkan pada saat harian dan evakuasi dan dapat dilihat pada Tabel.9.

Tabel 9. Kecepatan dan Waktu Tempuh

\begin{tabular}{|c|c|c|c|c|c|}
\hline $\begin{array}{c}\text { Kode Ruas } \\
\text { Jalan }\end{array}$ & $\begin{array}{l}\text { Jarak } \\
\text { (m) }\end{array}$ & $\begin{array}{c}\text { Tharian } \\
\text { (s) }\end{array}$ & $\begin{array}{c}\text { T evakuasi } \\
(\mathrm{s}) \\
\end{array}$ & $\begin{array}{l}\text { Vharian } \\
(\mathrm{km} / \mathrm{jam})\end{array}$ & $\begin{array}{c}\mathrm{V} \\
\text { evakuasi } \\
(\mathrm{km} / \mathrm{jam})\end{array}$ \\
\hline R-0l & 277,1 & 35,68 & 399,28 & 27,96 & 2,5 \\
\hline R-02 & 167,8 & 31,81 & 505,3 & 18,99 & 1,2 \\
\hline
\end{tabular}

\section{PEMBAHASAN}

Analisis hasil permodelan diatas mendapatkan nilai derajat kejenuhan, kecepatan, dan waktu tempuh di setiap ruas jalan yang dilalui pengungsi Gedung Kuliah Bersama V Universitas Bengkulu. Hasil permodelan tersebut akan dibandingkan pada kondisi harian untuk melihat seberapa besar dampak pergerakan model evakuasi yang terjadi. Pembahasan ini juga akan diperoleh beberapa solusi terakit evakuasi bencana tsunami dan pengembangan permodelan transportasi evakuasi pada penelitian ini

\section{Perbandingan derajat kejenuhan kondisi riil dan permodelan evakuasi}

Olahan data dilakukan untuk mencari derajat kejenuhan saat perjalanan harian dan perjalanan evakuasi di Gedung KuliahBersama V Universitas Bengkulu. Menunjukkan bahwa $\mathrm{Dj}$ harian pada ruas jalan R-01 sebesar 0,5411 dan pada ruas jalan R-02 sebesar 0,4931, dapat dilihat bahwa nilai derajat kejenuhan harian di ruas jalan R-01 berada di $0,5 \leq \mathrm{Dj} \leq 0,75$ yang berarti kondisi jalan stabil karena kapasitas dari ruas jalan dapat mengimbangi volume lalu lintas sehingga kendaraan dapat berjalan dengan kecepatan sedang. Sementara di ruas jalan R-02 berada di bawah 0,5 yang merupakan kondisi jalan sangat stabil karena volume lalu lintas sangat kecil jika dibandingkan dengan kapasitas ruas jalan yang ada sehingga kendaraan dapat berjalan dengan kecepatan tinggi. Sementara $\mathrm{Dj}$ saat evakuasi pada ruas jalan R-01 sebesar 0,3454 dan pada ruas jalan R-02 sebesar 0,3443, Nilai $\mathrm{Dj}$ saat evakuasi cenderung turun karena saat evakuasi pengungsi lebih memilih untuk berlari sehingga volume kendaraan menurun. Grafik derajat kejenuhan dapat dilihat pada Gambar 7.

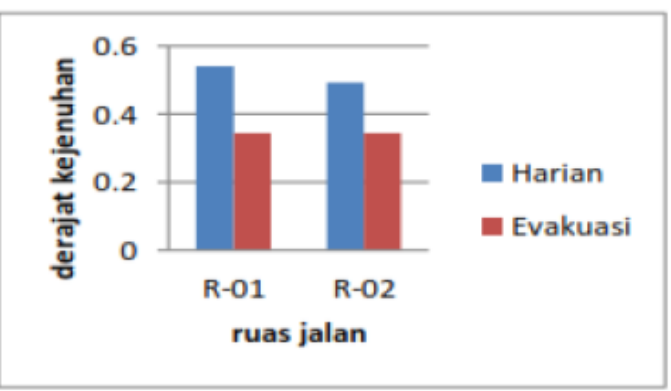

Gambar 7. Grafik Derajat Kejenuhan 


\section{Perbandingan Kecepatan Kondisi Riil dan Permodelan Evakuasi}

Kondisi kecepatan perjalanan agen di ruas jalan pada saat perjalanan harian dibandingkan pada saat permodelan evakuasi. Grafik kecepatan dapat dilihat pada Gambar 8. dari grafik dapat dilihat bahwa kecepatan saat evakuasi cenderung menurun, hal ini dikarenakan terjadi penumpukan pada ruas jalan yang diakibatkan oleh pengungsi yang bergerak serentak saat evakuasi.

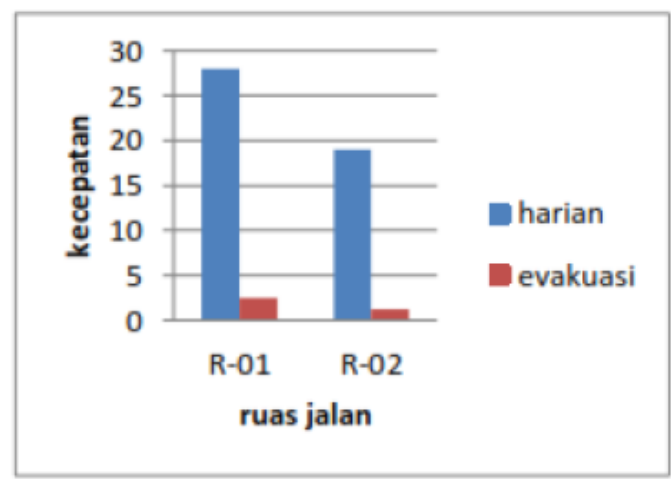

Gambar 8. Grafik Kecepatan

\section{Perbandingan Waktu Tempuh Kondisi Riil dan Permodelan Evakuasi}

Kondisi kecepatan perjalanan agen di ruas jalan pada saat perjalanan harian. Waktu tempuh total kendaraan sampai benar-benar mengosongkan wilayah kampus Universitas Bengkulu dalam permodelan adalah \pm 1000 ticks atau sama dengan 535 detik (8 menit 55 detik) perjalanan evakuasi. Grafik waktu tempuh dapat dilihat pada Gambar 9.

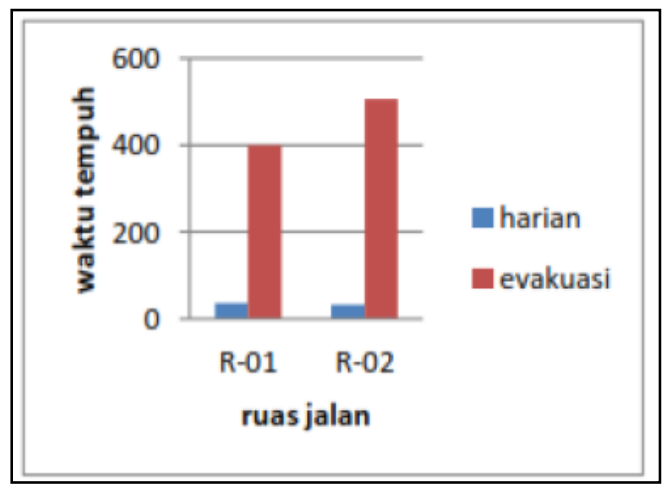

Gambar 9. Grafik Waktu Tempuh

\section{KESIMPULAN}

Penelitian mengenai permodelan transportasi evakuasi bencana tsunami di Gedung Kuliah Bersama V Universitas Bengkulu dapat disimpulkan dalam beberapa hal berikut:

1. Rancangan model yang dibangun menggunakan data populasi agen pada Gedung Kuliah Bersama V Universitas Bengkulu yang berjumlah 1970 orang. Kondisi jalan yang ditinjau pada pergerakan pengungsi saat evakuasi di jaringan jalan Universitas Bengkulu merupakan jaringan jalan lokal. Pilihan pergerakan pengungsi pada alternatif rute ruas jalan didistribusi berdasarkan kuisioner. Terdapat 2 ruas jalan yang ditinjau dari Gedung Kuliah Bersama V Universitas Bengkulu menuju pintu gerbang.

2. Perilaku pengungsi saat evakuasi $100 \%$ memilih rute dari Gedung Kuliah Bersama V Universitas Bengkulu langsung menuju gerbang kelur UNIB belakang (FT). Moda transportasi yang digunakan yaitu sepeda motor sebesar $52,08 \%$, mobil $1,04 \%$, dan lebih memilih berlari sebesar $46,88 \%$.

3. Kinerja jaringan jalan yang ditinjau memiliki Dj tertinggi pada ruas jalan $\mathrm{R}$ 01 yaitu dari GKB V sampai Fakultas Teknik yaitu sebesar 0,5411. Kecapatan kendaraan yang terjadi pada permodelan transportasi ini mengalami perlambatan di semua ruas jalan. Pengaruh perlambatan yang terjadi menyebabkan waktu tempuh yang dilalui pada setiap ruas jalan menjadi lebih lama. 


\section{DAFTAR PUSTAKA}

Badan Nasional Penanggulangan Bencana. 2017. Buku Saku Tanggap Tangkas Tangguh Menghadapi Bencana. Jakarta: BNPB.

Direktorat Jenderal bina Marga. 2014. Pedoman Kapasitas Jalan Indonesia. Jakarta: Direktorat Jenderal Bina Marga.

Hardiansyah, Muthohar, I., Priyanto, S., dan Suprama, L.B. 2016. Konsep Pemodelan Transportasi untuk Evakuasi Bencana. Jurnal Transportasi, Forum Studi Transportasi Antar Perguruan Tinggi. Volume 16. Jurusan Teknik Sipil. Fakultas Teknik. Universitas Katolik Parahyangan.
Jumadi, Carver, S. dan Quincey, D. 2016. A conceptual framework of volcanic evacuation simulation of Merapi using agent-based model and GIS. 34 November 2015. 402-409. Fakultas Geografi. Universitas Muhammadiyah Surakarta. Surakarta. Indonesia.

Rahma, I.S.Z. 2010. Analisis Faktor-Faktor Yang Mempengaruhi Permintaan Perumahan Tipe Cluster (Studi Kasus Perumahan Taman Sari) Kota Semarang. Skripsi Fakultas Ekonomi Universitas Diponegoro. Semarang. Republik Indonesia. 2007. Undang-undang Repulik Indonesia Nomor 24 Tahun 2007 Tentang penanggulangan Bencana. Jakarta: Sekretariat Negara. 